\title{
The Challenges of Human Resource Management Practices in the Informal Sector in Nigeria
}

\author{
Gbajumo-Sheriff Mariam, Elegbede Tunde, Owoyemi Oluwakemi \\ University of Lagos, Lagos, Nigeria
}

\begin{abstract}
Unemployment in the third world countries has led to various negative and positive challenges from brain drain, increased crime cases to emergent of entrepreneurial businesses. This paper examines the Nigerian informal sector and the extent of conformity with proper human resource practices. This paper adopts survey approach in analyzing data to test whether or not SMEs can conform to global HRM practices by analyzing some variables. Graphs and simple statistics were used to test the probability of conformity of informal sector activities with HRM practices in Nigeria. This paper also relied on secondary data from Bureau of Statistics and other government agencies. Past literatures were also examined. It was discovered that due to low capital outlay and inability to access funds from financial institutions, global human resource practices like proper recruitment, training, career development are being ignored.
\end{abstract}

Keywords: human resource practices, informal sector, entrepreneur

\section{Introduction}

According to Drucker, an entrepreneur is a person who understands the business opportunities and benefit by scarce resources and use them profitably. In his book Management, he said the purpose of an organization is to enable ordinary human beings to do extraordinary things, i.e., a means to make strengths productive and weakness irrelevant.

In Nigeria, the small and medium enterprises sub-sector has been expanding, especially since the mid-1980s, following the prolonged recession in the economy which forced many large enterprises to lay off large proportion of their work-force. The sector accounts for 70 percent of industrial employment (World Bank, 1995). Mazzarol, Volery, Doss and Thein (1999) indicated that emerging and transitional economies rely on small businesses in replacing state-owned organizations and stimulate economic growth.

A proper analysis of the developed economies of the advanced countries highlighted key imperatives needed to support the SME sector in its bid to opening the floodgates of economic prosperity. The key strategic imperatives identified, in order of priority, include provision of adequate infrastructure, sustained and sufficient institutional support, education and skills upgrading, technological adaptation and innovation and availability and access to funding and financial services.

In advanced economies, the SME sector is acclaimed as the engine of economic growth and development however against international best practices Nigeria is rated poorly. Extensive efforts in terms of strategic

Gbajumo-Sheriff Mariam, M.Sc, Department of Industrial Relations \& Personnel Management, University of Lagos.

Elegbede Tunde, M.Sc, Department of Industrial Relations \& Personnel Management, University of Lagos.

Owoyemi Oluwakemi, Ph.D., Department of Industrial Relations \& Personnel Management, University of Lagos. 
programmes, policy and practice will be required to elevate Nigeria to a leading position by 2020—Report of the Vision 2020 National Technical Working Group on Small and Medium Enterprises (SMEs), July, 2009.

In the more recent past, Nigerians adapted their natural talents to evolve traditional businesses and crafts that have sustained most of the country's rural and urban poor for the better part of the last half century. While the oil boom of the 1970s brought in billions of petrodollars, most of the country's population remained untouched by the new-found prosperity, thanks to widespread political corruption and catastrophic economic mismanagement. Because of these and other factors, the World Bank estimates that $80 \%$ of oil revenues benefited just $1 \%$ of the population.

Most of Nigeria's current woes trace back to a historic overdependence on oil to the negligence of all other sectors, including customary trades and agriculture. Decades of non-inclusive policies alienated the vast majority of Nigerians, plunging the country into a miasma of extreme poverty and ravaging civil and political strife. The climate of economic stagnation spawned a mammoth informal economy that continues to sustain the bulk of Nigeria's 148 million people. It is a measure of Nigeria's inherent entrepreneurial capacity that this informal, unorganized sector presently accounts for $65 \%$ of Gross National Product and accounts for $90 \%$ of all new jobs (Osalor, 2010).

\section{Literature Review}

There are no more important decisions within an organization than people decisions: staffing a job, placing people into jobs and into assignments, promoting people, letting them go, and so on. No matter how carefully organizations hire people, they won’t perform if put into jobs that are the wrong ones for them. No matter how brilliant and clever top management decisions are regarding a company's business or its strategy, its products, or services, they will not produce results if the company’s decisions do not work out (Drucker \& Maciariello, 2008).

The history of the informal sector started with the surplus production of goods. When they had created too many products in their domain they would trade that product for something else they needed (Maranda).

According to Yimothy S. Hatten in his book Small Business Management, Entrepreneurship and Beyond, he said some of the most valuable resources and competitive advantages a small business has are its employees. He also emphasized that there are too many costs and risks involved in not paying attention to human resource issues.

\section{The Need for Human Resource Management}

According to Fajana (2006), Human resource management is connected with concepts, theories (including models), policies, plans, programmes, strategies, procedures, rules and regulations that must be employed in the acquisition and utilization of men towards the achievement of organizational goals.

According to him, he divided the scope of HRM into 3 levels, viz:

- Before employment: Career choice, work design, technological change, self preparations, growth-related conflicts;

- During employment: Self development, motivation, leadership, trade unionism, counseling, on-the-job training, conflict management, workplace communication;

- Post-retirement: Exit interview, post-retirement follow-up, pension policies, job redesign and evaluation. Various aspect of human relevance to the informal sector:

- Recruitment and selection: This is to attract high calibre candidates and identification of candidates with the highest potential for performance for the job;

- Orientation and induction: This is to help new employee get acquitted with the organization, its policies, programmes and other colleagues. It includes training (on-the-job training, formal classroom training) during the 
introductory/probationary period;

- Training and development: This involves developing skills and learning concepts which are aimed at improving productivity. This could be in the form of in-house training, on-the-job training, apprenticeship and committee/group methods;

- The owner-manager as personnel manager, leadership style, time management, recognize the importance of time, reexamine and clarify priorities, analyze present time-consuming activities, implement time management principles;

- Motivation and loyalty, working conditions, employee needs, paying employees, fringe benefits, job rotation, job sharing, working from home, flexible hours, employee suggestion systems, controlling and evaluating performance, pinpoint, record, involve, coach, evaluate. This involves the use of integrated set of activities to ensure that the organization attracts, retains, motivates, and develops the talented people it needs now and in the future (Armstrong, 2006);

- Handling grievances, implement a method for expression grievances, assure that concerns will not affect relationships, minimal red tape, offer alternative methods, unionization and the small business, labor relations act;

- The owner-manager as personnel manager, leadership style, time management, recognition of the importance of time, re-examine and clarify priorities, analyze present time-consuming activities, implement time management principles;

- Exit interviews and post-retirement packages: This is to enhance commitment and sense of belongingness from employees. Adapted from Wesley D. Balderson, University of Lethbridge.

\section{The Informal Sector Examined}

The informal sector in Nigeria refers to economic activities in all sectors of the economy that are operated outside the purview of government regulation. This sector may be invisible, irregular, parallel, non-structured, backyard, underground, subterranean, unobserved or residual (Magbagbeola, 1996).

The traditional informal sector is defined crudely to include those labour intensive oftentimes self-employment economic activities which exist side by side with or partly dependent on the modern sector of the urban labour market (Fajana, 2000).

Activities in the informal sector in Nigeria are difficult to measure; they are highly dynamic and contribute substantially to the general growth of the economy and personal or household income (Ekpo \& Umoh, 2010).

The formal sector comprises of public sector and large private sector firms and industries whose operations are covered by existing product and factor markets' regulations. The informal sector on the other hand, is made up of small-scale firms and business enterprises that either do not comply at all, or only partially with existing markets regulations (Scherer, 1980; Goldberg \& Pavcnik, 2003; Folawewo, 2004; Olofin \& Folawewo, 2006).

The informal sector has continued to play a prominent role in these economies by way of income and employment generation activities. It is estimated that in sub-Saharan Africa, as much as over 50 percent of the entire workforce is employed in the informal sector (Vandemoortele, 1991). The slow pace of development, which has manifested in sluggish growth, poor industrial development and persistent high rate of unemployment, coupled with the economic crises of the early 1980s and political instability in a significant number of African states has led to the expansion of the informal sector in the region over the years (Olofin \& Folawewo, 2005, 2006).

Figure 1 compares the contribution of small businesses to GDP of various countries in 2005. 


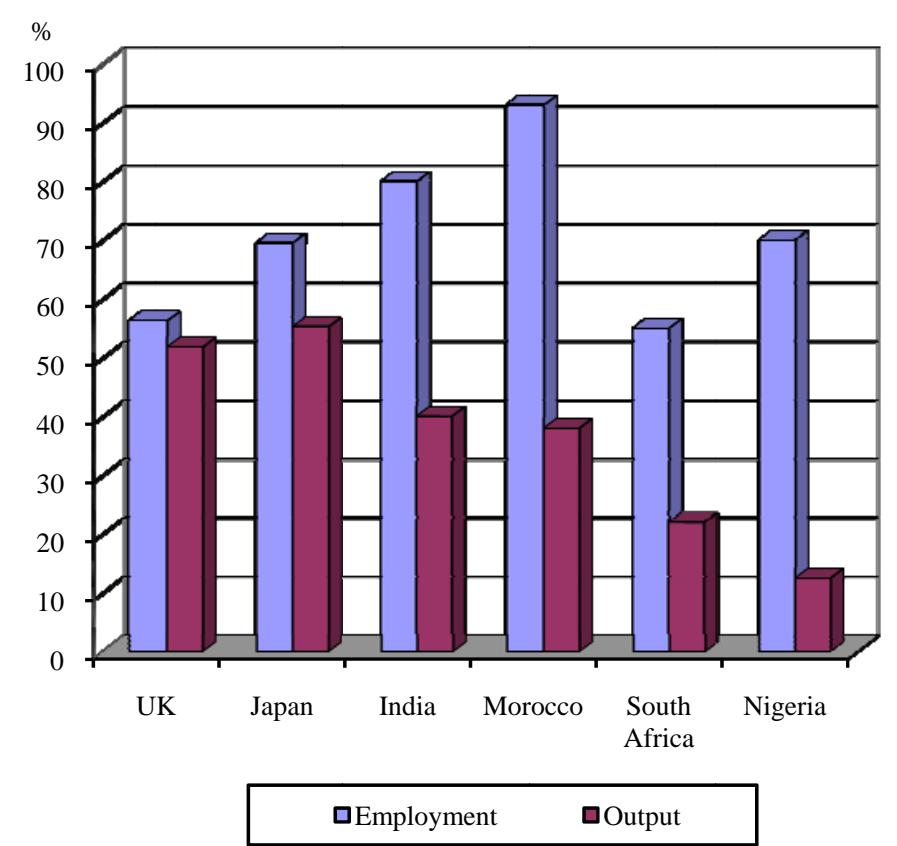

Figure 1. The contribution of small businesses to GDP of various countries in 2005. Source: SMEDAN, 2006, industrial sector figures only.

\section{State Intervention in the Informal Sector}

Given the uncertainty surrounding the current economic crisis and their own deteriorating balance sheets, many companies have not hesitated to make cuts in their workforce without realizing that in most cases, such measures will not solve fundamental problems and will more likely worsen the labor climate and worker motivation (Valle, 2008). Companies should aim at encouraging and stimulating entrepreneurial activities within the organization.

However, with more people being educated and the fact that government could no longer employ most school leavers, economic programs to encourage individuals to go into private business and be self reliant were initiated.

Two approaches are used for entrepreneurship development in Nigeria. One of them is concerned with the provision of generous credit facilities for small-scale industrialists with the aim of giving these entrepreneurs seed money. The second approach was the establishment of a training institution known as the Industrial Development Centre (IDC). The centre's purpose is to provide resources for on-the-job training of entrepreneurs in various aspects of industrial management-especially those in the informal sector, such as petty traders, artisans, or farmers. Unfortunately, these initiatives failed to achieve desired results.

Such economic policy programs that are geared towards self reliance for individuals are programs as Open Apprenticeship Scheme, Graduate Employment Programs etc. and other policies that encourage or make it easy for entrepreneurs to acquire the needed funds, e.g., Peoples Bank of Nigeria, Funds for Small-Scale Industries(FUSSI), co-operative societies etc. were established to assist entrepreneurs in Nigeria.

One of the major factors that have in many ways discouraged this flow of entrepreneurship development in Nigeria is the value system brought about by formal education. For many decades, formal education has been the preserve of the privilege. With formal education people had the opportunity of being employed in the civil service, because in those days the economy was large enough to absorb into the prestigious occupation all Nigerians their 
goods. As such, the system made Nigerians to be dependent on the colonial masters (Nicks, 2008).

\section{Barriers to Youth Entrepreneurship}

The country's entrepreneurial potential also remains stunted due to entrenched systemic weaknesses. These challenges include:

- Low standard of education: Education is a crucial factor in preparing and empowering young entrepreneurs with business-related skills. Unfortunately, the role of education in preparing young people to become agents of change has largely been ignored in Nigeria. Year after year, education quality declines. The country has also experienced brain drain due to lack of proper incentives. Those stuck in the system are often only there due to an absence of alternative jobs;

- Inadequate basic infrastructure: Significant infrastructural deficits (especially with regards to roads and electricity) and systemic irregularities are inimical to small businesses;

- Government policies: Or lack of it thereof, has been a major bane of education in Nigeria. Schools are not adequately funded, equipped, or managed to bring out students' potential. Most of the time, students stay home due to strikes called by teachers. Most people in government send their children abroad for their education, neglecting the urgent need for reforms. The result is a workforce lacking in the skills and confidence needed for a better quality of life in Nigeria. Also, the absence of a pro-active regulatory environment discourages innovative enterprise development at the grassroots level;

- Inadequate training: The absence of adequate training for students that would help them become future business and community leaders is a regrettable consequence of poor education. The educational curriculum in Nigeria focuses heavily on theory without a corresponding practical approach. As a result, most employers are compelled to retrain their young employees due to their lack of basic workplace skills. Where some practical training is offered, it is usually directed at the employees of larger companies that can afford the exorbitant fees charged by the training institutions. With little or no money to spare, most young people miss these opportunities to equip themselves for leadership roles, resulting in low morale, inefficiency, and lack of confidence. Poor access to vocational and skills-development training for rural and urban youths involved in the informal economy constitutes a problem and affect the informal sector;

- Lack of proper technology: Technology has the potential to improve quality of life and economic performance. When youth do not have the knowledge or skills to use the latest technology, it affects their outlook on life. It is surprising that in an age when computers and the internet are taken for granted in so many parts of the world, the reverse is the case in Nigeria. The internet and other information and communications technology (ICT) infrastructure are not available in rural areas, where the majority of the Nigerian youth reside. This situation denies them an alternative means of skill acquisition, information access, and other advantages. Consequently, employers prefer to hire experienced professionals, making it impossible for young people to acquire much needed skills, familiarity with the work environment, or basic tools to pioneer their own successful businesses;

- Other economic, social, and political factors: There are other elements that play a role in stifling the dreams and aspirations of the Nigerian youth. Economic factors such as policy reversals, high and double taxation, difficulty in procuring business licenses, high inflation, and unstable exchange rates are some concern areas for potential entrepreneurs. Registering businesses is also incredibly difficult: An entrepreneur must procure a lawyer and an accountant to confront the legal and financial aspects of starting a business. The presence of administrative and trade barriers also curtails capacity building and inhibit access to technical support. 
Here is the result of a study conducted by Doing Business in Nigeria 2010 which is a collaboration between the World Bank Investment Climate Team for Africa, the subnational Doing Business team and the UK Department for International Development (DFID), the Government of Germany, through the Gesellschaft für Technische Zusammenarbeit (GTZ), and the Government of Switzerland, through the State Secretariat for Economic Affairs (SECO) (see Table 1).

Table 1

Best Practice in Nigeria Compared Internationally

\begin{tabular}{|c|c|c|c|c|c|}
\hline & \multicolumn{2}{|c|}{$\begin{array}{c}\text { Nigeria in DB } 2010 \\
\text { (represented by Lagos) }\end{array}$} & \multicolumn{3}{|c|}{ Nigeria best practice } \\
\hline Indicator & Performance & $\begin{array}{c}\text { Global rank } \\
\text { (183 economies) }\end{array}$ & $\begin{array}{c}\text { Best-performing state } \\
\text { within Nigeria }\end{array}$ & Performance & $\begin{array}{c}\text { Global rank } \\
\text { (183 economies). } \\
\text { How Nigerian } \\
\text { States would } \\
\text { compete globally }\end{array}$ \\
\hline $\begin{array}{l}\text { Days to deal with } \\
\text { construction permits }\end{array}$ & 350 days & 167 & Jigawa & 47 days & 6 \\
\hline $\begin{array}{l}\text { Number of procedures to } \\
\text { deal with construction } \\
\text { permits }\end{array}$ & 18 procedures & 101 & Jigawa & 10 Procedures & 9 \\
\hline Days to enforce a contract & 457 days & 64 & Jigawa & 261 days & 10 \\
\hline $\begin{array}{l}\text { Number of procedures to } \\
\text { start a business }\end{array}$ & 8 procedures & 94 & Abuja, FCT & 5 Procedures & 25 \\
\hline Days to register property & 82 days & 140 & Borno & 14 days & 26 \\
\hline $\begin{array}{l}\text { Cost to deal with } \\
\text { construction permit }\end{array}$ & $\begin{array}{c}580.3 \% \text { of income } \\
\text { per capita }^{a}\end{array}$ & 143 & Kano & $\begin{array}{l}94.6 \% \text { of income } \\
\text { per capita }\end{array}$ & 67 \\
\hline Days to start a business & 31 days & 117 & Abuja, FCT & 22 days & 92 \\
\hline Cost to register property & $\begin{array}{l}20.9 \% \text { of the } \\
\text { property value }\end{array}$ & 178 & Yobe & $\begin{array}{l}5.2 \% \text { of the } \\
\text { property value }\end{array}$ & 104 \\
\hline $\begin{array}{l}\text { Number of procedures to } \\
\text { register property }\end{array}$ & 13 Procedures & 177 & $\begin{array}{l}\text { Borno, Gombe, } \\
\text { Kwara }\end{array}$ & 8 Procedures & 136 \\
\hline $\begin{array}{l}\text { Cost to start a business } \\
77.0 \% \text { of income }\end{array}$ & $\begin{array}{l}\text { 77.0\% of income } \\
\text { per capita }^{b}\end{array}$ & 153 & Abuja, FCT & $\begin{array}{l}58.5 \% \text { of income } \\
\text { per capita }\end{array}$ & 148 \\
\hline
\end{tabular}

Notes. ${ }^{a}$ At the time of publication of Doing Business 2010: Reforming through difficult times the cost was 573.4\% of income per capita; ${ }^{b}$ At the time of publication of Doing Business 2010: Reforming through difficult times the cost was 76.7\% of income per capita. Source: Doing Business 2010 database.

Doing Business in Nigeria 2010 provides a quantitative measure of the federal and state regulations for starting a business, dealing with construction permits, registering property, and enforcing contracts—as they apply to domestic small and medium-size enterprises.

Benchmarking exercises like Doing Business inspire governments to reform. They uncover potential challenges and identify where policy makers can look for good practices. Comparisons between cities within the same country are even stronger drivers of reform, because local governments have a hard time explaining why doing business in their city or state may be harder than in neighbouring locations. The good news is that sharing a national legal framework facilitates the implementation of existing good practices within a country. National governments can also use Doing Business data to monitor how local branches of their agencies implement national regulations. In a world where locations compete against each other to attract investment, subnational Doing Business data allow local governments to review the conditions facing entrepreneurs in their cities from a comparative perspective (Doing Business in Nigeria, 2010). 
This result shows that doing business in Nigeria is bureaucratic and filled with various bottlenecks. This, of course will deter young entrepreneurs from getting into the business.

The resulting social malaise from systemic corruption dissuades many people from venturing into business. All too often, it seems that gaining legal approval is coupled with some kind of favour to the person or authority granting the approval. Frustrated youth look away from entrepreneurship, frequently to the public sector where they are certain they will collect their pay at the end of every month without the worries associated with running a business (Onwubiko, 2005).

\section{Why the Informal Sector?}

When the Obama administration started work on a massive stimulus bill to revive the economy, it remained to be seen how strongly the new president focused on small businesses. Numerous studies over the years have found that small businesses and start-ups create anywhere from 60 percent to 80 percent of all new jobs, which is something the economy desperately needs right now. To create jobs, however, small businesses need access to capital. It’s the life-blood of any new or growing business (Girard, 2005) (see Table 2 and Figure 2).

Table 2

National Unemployment Rates 2000-2009

\begin{tabular}{ll}
\hline Year & Rates \\
\hline 2000 & 13.1 \\
2001 & 13.6 \\
2002 & 12.6 \\
2003 & 14.8 \\
2004 & 13.4 \\
2005 & 11.9 \\
2006 & 12.3 \\
2007 & 12.7 \\
2008 & 14.9 \\
2009 & 19.7 \\
\hline
\end{tabular}

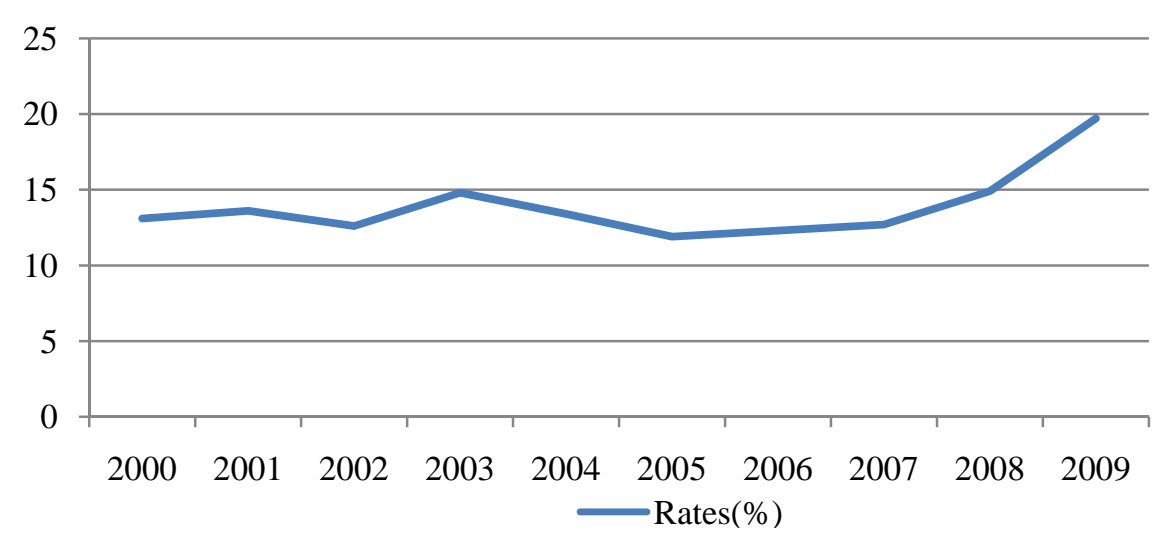

Figure 2. National unemployment rates, Nigeria 2000-2009. Source: Labour Force Survey, March, 2009; National Bureau of Statistics.

Analyzing Figure 3, Nigeria may move from 8th most populous to a projected 7th most populous country of 206m in 2025 with more people living in cities. Nigeria has been and will continue to experience a high 
population growth rate and the base population consists of mainly people within the working age group. It can be reasonable to deduce the following:

(1) The population will consist of groups within the working age group who are unable to find paid employment;

(2) There will be consumers who have needs to be met by trade hence the relevance of informal sector;

(3) This will spur the entrepreneurship business as people must be employed and this can mostly be achieved by trade and this will spur small and medium scale businesses (MTNN Enterprise Solutions Conceptual Segmentation Framework Research for MSME 2010).
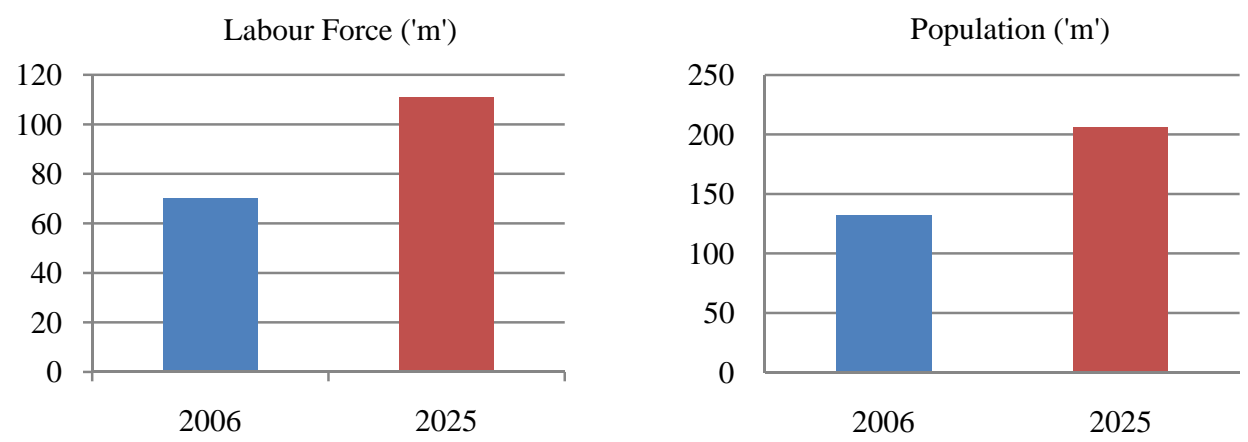

Figure 3. Projection of Nigerian population and labour force by 2025. Source: MTNN Enterprise Solutions Conceptual Segmentation Framework Research for MSME 2010.

\section{Research Methodology}

This paper relied on secondary data from Bureau of Statistics, Small and Medium Enterprises Development Agency of Nigeria (SMEDAN) and other government agencies. Past literatures were also examined.

The Small and Medium Enterprises Development Agency of Nigeria (SMEDAN) in collaboration with the United Nations Development Programme (UNDP) conducted a baseline survey of Micro, Small and Medium Enterprises (MSMEs) in six major commercial centres of Nigeria including Aba, Abuja, Kaduna, Kano, Nnewi and Port-Harcourt. Michael Jacobs consulting was contracted to carry out the survey. The paper focused only on 2 areas which are Aba and Abuja. This is because these are the main commercial centres in Nigeria out of all the centres and business transactions and industrial layouts are concentrated in these areas. The methodology employed in carrying out this survey was face to face interviews making use of questionnaires. After the design of the questionnaire, it was vetted by other consultants and tested on the field to assess the applicability of the questionnaires. Amendments were made and the final copy of the questionnaire was then sent to SMEDAN for their approval and validation. In this survey, a total of 2,786 questionnaires were administered within Aba metropolis excluding some questionnaires that were found to be invalid. Two thousand, seven hundred and eighty six were analyzed basically on frequencies. The statistical Package for Social Sciences (SPSS) was used to run the analysis and graphs developed.

Five local government areas were visited in this study. In Aba North Local Area Council 612 respondents were interviewed, Aba South 1,138, Obingwa 8, Osisioma 943 and Ugwunagbo 85 respectively. Aba South and Osisioma have the highest number of entrepreneurs interviewed. Another reason for this is the major markets sited in these local government areas. 


\section{Research Analysis}

This section is to analyze the data gathered from the survey in order to establish whether good HRM practices in terms of training, planning, hiring decisions and career development are in the informal sector. Some variables are used in order to determine the level of exposure of the informal to risks associated with vague HR practices.

Table 3

Educational Background of Proprietor

\begin{tabular}{|c|c|c|c|c|c|}
\hline & & Frequency & Percent & Valid percent & Cumulative percent \\
\hline \multicolumn{6}{|l|}{ Abuja } \\
\hline \multirow[t]{4}{*}{ Valid } & Graduate & 796 & 34.0 & 34.0 & 34.0 \\
\hline & SSCE & 1,324 & 56.5 & 56.5 & 90.4 \\
\hline & Primary school leaving certificate & 219 & 9.3 & 9.3 & 99.8 \\
\hline & No formal education & 5 & 0.2 & 0.2 & 100.0 \\
\hline Total & & 2,344 & 100.0 & 100.0 & \\
\hline \multicolumn{6}{|l|}{ Aba } \\
\hline \multirow[t]{4}{*}{ Valid } & Graduate & 369 & 13.2 & 13.2 & 13.2 \\
\hline & SSCE & 2,046 & 73.4 & 73.5 & 86.7 \\
\hline & Primary school leaving certificate & 367 & 13.2 & 13.2 & 99.9 \\
\hline & No formal education & 3 & 0.1 & 0.1 & 100.0 \\
\hline Total & & 2,785 & 100.0 & 100.0 & \\
\hline Missing & System & 1 & 0.0 & & \\
\hline Total & & 2,786 & 100.0 & & \\
\hline
\end{tabular}

Note. Source: SMEDAN.

From Table 3, it can be deduced that only 34\% of the respondents in Abuja have tertiary institutions education while the percentage is lower in Abuja with 13.2\%.

Table 4

Registration Type

\begin{tabular}{|c|c|c|c|c|c|}
\hline & & Frequency & Percent & Valid percent & Cumulative percent \\
\hline \multicolumn{6}{|l|}{ Abuja } \\
\hline \multirow[t]{4}{*}{ Valid } & None & 1,354 & 57.8 & 57.8 & 57.8 \\
\hline & Business name & 564 & 24.1 & 24.1 & 81.9 \\
\hline & Partnership & 75 & 3.2 & 3.2 & 85.1 \\
\hline & Limited liability & 350 & 14.9 & 14.9 & 100.0 \\
\hline \multirow[t]{3}{*}{ Missing } & Total & 2,343 & 100.0 & 100.0 & \\
\hline & System & 1 & 0 & & \\
\hline & & 2,344 & 100.0 & & \\
\hline \multicolumn{6}{|l|}{ Aba } \\
\hline \multirow[t]{5}{*}{ Valid } & None & 1,596 & 57.3 & 57.3 & 57.3 \\
\hline & Business name & 681 & 24.4 & 24.4 & 81.7 \\
\hline & Partnership & 84 & 3.0 & 3.0 & 84.7 \\
\hline & Limited liability & 425 & 15.3 & 15.3 & 100.0 \\
\hline & Total & 2,786 & 100.0 & 100.0 & \\
\hline
\end{tabular}

Note. Source: SMEDAN. 
The analysis of Table 4 show that $57.8 \%$ of the respondents in Abuja do not have businesses registered and 57.3\% in Aba do not have their business registered. This means that they have not realized the benefits of having their companies registered.

Table 5

Has Had Vocational/Entrepreneurship Training in the Past

\begin{tabular}{llrrrr}
\hline & & Frequency & Percent & Valid percent & Cumulative percent \\
\hline Abuja & & & & & 79.5 \\
\hline Valid & Yes & 1,860 & 79.4 & 79.5 & 100.0 \\
No & 481 & 20.5 & 20.5 & 100.0 & \\
Missing & & 2,341 & 99.9 & & 20.2 \\
\hline Total & System & 3 & 1 & & 100.0 \\
\hline Aba & & 2,344 & 100.0 & \\
\hline Valid & Yes & 563 & 20.2 & & \\
\hline
\end{tabular}

Note. Source: SMEDAN.

The result of Table 5 shows that $20.5 \%$ of the Abuja respondents and $79.8 \%$ of the Aba respondents have not undergone any type of training while most of those that had been trained had just one training from their former masters. Most of them just got in the sector without prior training, hence the need for on-the-job training.

Table 6 shows that $94.2 \%$ and $83.4 \%$ of the respondents in Abuja and Aba respectively have no plan beyond 3 years. Also 3.6\% and 2.6\% of the respondents in Abuja and Aba respectively have no plan at all. This is not surprising because their level of education may not give them the exposure to know the need for long term planning.

Table 6

Number of Years Planned Ahead

\begin{tabular}{|c|c|c|c|c|c|}
\hline & & Frequency & Percent & Valid percent & Cumulative percent \\
\hline \multicolumn{6}{|l|}{ Abuja } \\
\hline \multirow[t]{6}{*}{ Valid } & Under 1 year & 1,767 & 75.4 & 75.4 & 75.4 \\
\hline & $1-3$ years & 441 & 18.8 & 18.8 & 94.2 \\
\hline & 4-5 years & 32 & 1.4 & 1.4 & 95.6 \\
\hline & 5 year above & 20 & 0.9 & 0.9 & 96.4 \\
\hline & Never applied planning & 84 & 3.6 & 3.6 & 100.0 \\
\hline & Total & 2,344 & 100.0 & 100.0 & \\
\hline \multicolumn{6}{|l|}{ Aba } \\
\hline \multirow[t]{6}{*}{ Valid } & Under 1 year & 773 & 27.7 & 27.7 & 27.7 \\
\hline & $1-3$ years & 1,550 & 55.6 & 55.6 & 83.4 \\
\hline & 4-5 years & 218 & 7.8 & 7.8 & 91.2 \\
\hline & 5 year above & 172 & 6.2 & 6.2 & 97.4 \\
\hline & Never applied planning & 73 & 2.6 & 2.6 & 100.0 \\
\hline & Total & 2,786 & 100.0 & 100.0 & \\
\hline
\end{tabular}

Note. Source: SMEDAN. 


\section{Summary and Conclusions}

Human resource practice in the informal sector in Nigeria is at its infancy. There are other pressing needs like raising capital for expansion and adhering to various government laws and regulations relating to small scale businesses.

It can be seen from the analysis that:

(1) The percentage of informal sector operators that are uneducated is alarming;

(2) This seems to be affecting their view of business in terms of planning, i.e., short plan or even no planning at all;

(3) Most of the businesses are not registered due to lack of awareness;

(4) Some of the business owners have had access to little or no vocational training in respect of their trade.

This shows that there is need for more awareness on its negative effects of improper HRM on the organization and its employees alike. This can be reduced by using the services of professionals to shape the informal sector to be able to compete internationally. It is envisaged that this enigmatic and ugly situation requires immediate and concerted efforts to shape a new directional focus that will ensure an efficient and effective human resource practice in Nigeria's informal business sector.

In view of these facts, the following suggestions are advanced with a view to reversing the situation at a minimal cost.

\section{Employers}

- There is need for more awareness programs on the negative effects of improper HRM on the organisation and its employees alike;

- Given the uncertainty surrounding the current economic crisis and their own deteriorating balance sheets, many companies have not hesitated to make cuts in their workforce without realizing that in most cases, such measures will not solve fundamental problems and will more likely worsen the labor climate and worker motivation (Cabrera, 2008).The company should aim at encouraging and stimulating entrepreneurial activities;

- Engage the services of professionals in order to make better planning, hiring and career development decisions. There should also be strict adherence to professional instructions;

- Design retirement plans for employees to increase motivation and sense of belongingness;

- The company should aim at encouraging and stimulating entrepreneurial activities.

\section{Government}

- The government should intensify awareness campaign in order to train and expose small business owner on the need to engage in best human resource practices;

- There should be a conscious effort at including entrepreneurship courses in University Degree curriculum;

- Government should create a conducive environment for business by eliminating business start-up bottlenecks;

- Government should closely monitor the loan profile of banks in order to ensure that small-scale entrepreneurs benefit from them.

\section{References}

Ajakaiye, O., \& Akerele, W. O. (1996). Overview of conceptual and methodological issues in informal sector research. Armstrong, M. (2006). A handbook of human resource management practice. London, United Kingdom 
Cabrera, R. V. (2008). Managing talent during a period of crisis. Retrieved August 15, 2010, from http://www.wharton.universia.net/index.cfm?fa=viewArticle\&id=1597\&language=english

Central Bank of Nigeria Statistical Bulletin. (2005, December). Retrieved August 1, 2010, from http://www.cenbank.org/out/publications/reports/rd/2007/stabull-2005.pdf

Ekpo, A. H., \& Umoh, O. J. (2010). The informal sector, Online Nigeria. Retrieved August 17, 2010, from http://www.onlinenigeria.com/economics/?blurb=495

Girard, K. (2009, February 5). Small business stimulus bill: Is "half a loaf” enough? Retrieved August 15, 2010, from http://www.allbusiness.com/government/government-bodies-offices-legislative/11772431-1

Goldberg, P. K., \& Pavcnik, N. (2003). The response of the informal sector to trade liberalisation. NBER working paper 9443, Cambridge, MA: National Bureau of Economic Research.

Mazzarol, T., Volery, T., Doss, N., \& Thein, V. (1999). Factors influencing small business start-ups: A comparison with previous research. International Journal of Entrepreneurial Behaviour \& Research, 5(2), 48-63.

Nicks. (2008, May 24). The history of entrepreneurship in Nigeria. Retrieved on August 10, 2010, from http://bizcovering.com/history/the-history-of-entrepreneurship-in-nigeria/\#ixzz0sQ2Ayame

Olofin, S. O., \& Folawewo, A. O. (2005). Modeling the informal sector in African economies. Paper presented at the Annual Conference of the African Econometric Society (AES), Nairobi, Kenya, July 6-8, 2005.

Olofin, S. O., \& Folawewo, A. O. (2006). Skill requirements, earnings and labour demand in Nigeria's urban informal sector. In B. Guha-Khasnobis, \& R. Kanbur (Eds.), Informal Labour Markets and Development. Palgrave Macmillan, 180-195, prepared for the joint WTO-ILO Workshop on Global Trade and Employment, August 31-September 1, 2009, Geneva, Switzerland.

Omodia, S. (2009). Manpower development in Nigeria: Conceptual and methodological perspectives. Retrieved August 13, from http://www.krepublishers.com/02-Journals/JSS/JSS-18-0-000-09-Web/JSS-18-2-000-2009-Abst-PDF/JSS-18-2-113-09-715Monday-O-S/JSS-18-2-113-09-715-Monday-O-S-Tt.pdf

Onwubiko, C. M. (2008). Nigeria's imperative for youth-led entrepreneurial development, 2-4.

Osalor, P. (2010). Entrepreneurial development in Nigeria. Retrieved on August 15, 2010, from http://ezinearticles.com/?Entrepreneurial-Development-in-Nigeria\&id=3562102

Scherer, F. M. (1980). Industrial market structure and economic performance. Chicago: Rand Mcnally Company.

United Nations. (2009). Human development report. New York.

Vandemoortele, J. (1991). Labour market informalisation in sub-saharan Africa. In G. Standing, \& V. Tokman (Eds.), Towards social adjustment: Labor market issues in structural adjustment. Geneva: ILO. 